\title{
ANALISIS PENJADWALAN PROYEK NEW PRODUCT DEVELOPMENT MENGGUNAKAN METODE PERT DAN CPM
}

\author{
Atica Angelin dan Silvi Ariyanti \\ Program Studi Teknik Industri Universitas Mercu Buana \\ e-mail: pasti@mercubuana.ac.id
}

\begin{abstract}
ABSTRAK
Perencanaan dan pengendalian suatu proyek memiliki peran penting untuk kelancaran dan keberhasilan pelaksanaan proyek. Kegagalan dalam suatu proyek dapat disebabkan oleh perencanaan yang kurang matang serta pengendalian yang kurang efektif sehingga dapat menyebabkan keterlambatan dan menurunnya kualitas sehingga kegiatan proyek menjadi tidak efisien. Dalam pelaksanaannya, durasi proyek dibatasi oleh jadwal yang telah ditentukan sehingga pimpinan yang terlibat dalam proyek harus dapat mengantisipasi perubahan kondisi yang terjadi. Adapun untuk pelaksanaan proyek tersebut memerlukan perencanaan proyek yang optimal dengan memanfaatkan metode CPM dan PERT. Dengan membandingkan kedua metode tersebut dihasilkan data bahwa dengan menggunakan metode CPM menghasilkan durasi penyelesaian proyek yang lebih cepat. Durasi yang dibutuhkan untuk menyesaikan proyek dengan metode CPM adalah 101 hari dan dengan PERT 102 hari. Dengan metode CPM dapat dilakukan percepatan waktu penyelesaian proyek 34\% dari jadwal proyek eksisting.
\end{abstract}

Kata kunci: penjadwalan, perencanaan, CPM, PERT.

\begin{abstract}
Planning and controlling a project has an important role for the smooth and successful implementation of the project. Failure in a project can be caused by poor planning and ineffective control so that it can cause delays and decreases in quality so that project activities become inefficient. In practice, the duration of the project is limited by a predetermined schedule so that the leaders involved in the project must be able to anticipate changes in conditions that occur. As for the implementation of the project requires optimal project planning by utilizing the CPM and PERT methods. By comparing the two methods, the data is generated, that using the CPM method results in a faster duration of project completion. The duration needed to complete the project with the CPM method is 101 days and with PERT 102 days. With the CPM method, the project completion time can be accelerated 34\% of the existing project schedule.
\end{abstract}

Keywords: schedulling, planning, CPM, PERT

\section{PENDAHULUAN}

Perencanaan kegiatan-kegiatan proyek merupakan masalah yang sangat penting karena perencanaan kegiatan merupakan dasar untuk proyek bisa berjalan dan agar proyek yang dilaksanakan dapat selesai dengan waktu yang optimal. Pada tahapan perencanaan proyek, diperlukan adanya estimasi durasi waktu pelaksanaan proyek. Realita di lapangan menunjukkan bahwa waktu penyelesaian sebuah proyek bervariasi, akibatnya perkiraan waktu penyelesaian suatu proyek tidak bisa dipastikan akan dapat ditepati. Tingkat ketepatan estimasi waktu penyelesaian proyek ditentukan oleh tingkat ketepatan perkiraan durasi setiap kegiatan di dalam proyek. Selain ketepatan perkiraan waktu, penegasan hubungan antar kegiatan suatu proyek juga diperlukan perencanaan suatu proyek.

Jadwal merupakan salah satu parameter yang menjadi tolak ukur keberhasilan suatu proyek, disamping anggaran dan mutu. Penjadwalan perlu diperhatikan dalam manajemen proyek untuk menentukan durasi maupun urutan kegiatan proyek, sehingga terbentuklah penjadwalan yang logis dan realistis. Pada umumnya, penjadwalan proyek menggunakan estimasi durasi yang pasti. Namun, banyak faktor ketidakpastian (uncertainty) sehingga durasi masing-masing kegiatan tidak dapat ditentukan dengan pasti.

Permasalahan yang terjadi pada bagian NPD di PT. XYZ adalah terdapat ketidaksesuaian data aktual dengan jadwal yang telah direncanakan terlebih dahulu, terdapat 
beberapa masalah yang menyebabkan delay pada tahap-tahap tertentu. Penelitian ini bertujuan untuk menganalisis jadwal proyek dengan menggunakan metode PERT (Project Evaluation and Review Technique) dan CPM (Critical Path Method) sehingga dapat diketahui berapa lama suatu proyek dapat diselesaikan dan mencari adanya kemungkinan percepatan waktu pelaksanaan proyek.

Penelitian sebelumnya tentang perencanaan dan penjadwalan proyek menggunakan PERT dan CPM telah banyak dilakukan, misalnya dikombinasikan dengan teknik linear programming [1]. Maupun aplikasi penjadwalan proyek pada Unit Startup [2], terbukti dengan menggunakan metode PERT dan CPM mampu mengurangi waktu penyelesaian proyek menjadi lebih cepat.

\section{Penjadwalan Proyek}

Jadwal adalah penjabaran perencanaan proyek menjadi urutan langkah-langkah pelaksanaan pekerjaan untuk mencapai sasaran. Pada jadwal telah dimasukan faktor waktu. Metode menyusun jadwal yang terkenal adalah analisis jaringan (network), yang menggambarkan dalam suatu grafik hubungan urutan pekerjaan proyek. Pekerjaan yang harus mendahului atau didahului oleh pekerjaan lain diidentifikasi dalam kaitanya dengan waktu. Jaringan kerja ini sangat berguna untuk perencanaan dan pengendalian proyek [3].

Penjadwalan adalah kegiatan untuk menentukan waktu yang dibutuhkan dan urutan kegiatan serta menentukan waktu proyek dapat diselesaikan [4]. Penjadwalan proyek merupakan sesuatu yang lebih spesifik dan menjadi bagian dari perencanaan proyek. Penjadwalan proyek dicantumkan tentang penetapan waktu, tahapan pelaksanaan kegiatan-kegiatan seperti yang telah direncanakan semula [5].

\section{CPM (Critical Path Method)}

CPM (Critical path Method) yang dikenal sebagai jalur kritis, dikembangkan oleh J.E Kelly dari perusahaan Remington Rand dan M.R Walker dari DuPont dalam rangka mengembangkan suatu sistem kontrol manajemen. Sistem ini dimaksudkan untuk merencanakan dan mengendalikan sejumlah besar kegiatan yang memiliki ketergantungan yang kompleks dalam masalah desain dan konstruksi. Melalui metode jalur kritis, pelaksana dapat mengetahui pekerjaanpekerjaan yang rawan dan berpengaruh dalam keseluruhan proses kerja. Apabila terjadi keterlambatan dan dengan mengetahui letak keterlambatan, maka dalam pelaksanaannya dapat dilakukan tindakan antisipasi atas ketidakefisienan waktu yang terjadi sebelumnya, sehingga keterlambatan di satu bagian tidak merambat ke pekerjaan lainnya. Dalam proses identifikasi jalur kritis ada beberapa istilah atau pengertian yang digunakan, yaitu sebagai berikut [6].

Earliest Start Time (ES) adalah waktu paling awal (tercepat) suatu kegiatan dapat dimulai, dengan memperhatikan waktu kegiatan yang diharapkan dan persyaratan urutan pengerjaan.

Latest Start Time (LS) adalah waktu paling lambat untuk dapat memulai suatu kegiatan tanpa penundaan keseluruhan proyek.

Earliest Finish Time (EF) adalah Waktu paling awal kegiatan dapat diselesaikan, atau sama dengan ES + Waktu kegiatan yang diharapkan.

Latest Finish Time (LF) adalah waktu paling lambat untuk dapat menyelesaikan suatu kegiatan tanpa penundaan penyelesaian proyek secara keseluruhan, atau sama dengan LS + waktu kegiatan yang diharapkan.

\section{PERT (Project Evaluation and Review Technique)}

PERT merupakan suatu metode yang bertujuan untuk (semaksimal mungkin) mengurangi adanya penundaan kegiatan (proyek, produksi, dan teknik) maupun rintangan dan perbedaan-perbedaan, mengkoordinasikan dan menyelaraskan berbagai bagian sebagai suatu keseluruhan pekerjaan dan mempercepat selesainya proyekproyek [7]. Sebuah fitur yang membedakan PERT adalah kemampuannya untuk menghadapi ketidakpastian di masa penyelesaian kegiatan. Untuk setiap aktivitas, model biasanya mencakup tiga perkiraan waktu yaitu waktu optimis adalah perkiraan waktu 
yang mempunyai kemungkinan yang sangat kecil untuk dapat dicapai, kemungkinan terjadinya hanya satu kali dari 100, waktu pesimis adalah suatu perkiraan waktu yang lain yang mempunyai kemungkinan sangat kecil untuk dapat direalisasikan, kemungkinan terjadinya juga hanya satu kali dalam 100, sedangkan waktu realistis atau waktu yang paling mungkin adalah waktu yang berdasarkan pikiran estimator. Perkiraan waktu optimis biasanya dinyatakan dengan huruf $a$, waktu realistis dengan huruf $m$, dan waktu pesimis dinyatakan dengan huruf $b$.

Rumus PERT adalah:

$$
\begin{aligned}
& T e=(a+m+b) / 6 \\
& V=[(b-a)] / 6^{2} \\
& Z=T s-T e / \sqrt{ } \Sigma V^{2}
\end{aligned}
$$

Keterangan :

Te : Waktu yang diharapkan (expected duration)

$a$ : Waktu paling optimis (minimum)

$m$ : Waktu paling mungkin terjadi (most likely) $b \quad$ : Waktu paling lambat (maximum)

$V$ : Varian

$Z \quad$ : Deviasi standar dari distribusi normal

Ts : Ekspektasi waktu penyelesaian

Te : Waktu penyelesaian yang dikehendaki (expected duration)

\section{METODOLOGI PENELITIAN}

Penelitian ini bertujuan untuk menentukan kegiatan-kegiatan kritis dalam proyek development packaging menggunakan metode PERT dan CPM. Analisis data menggunakan metode analitis dan deskriptif. Analitis berarti data yang sudah ada diolah sedemikian rupa sehingga menghasilkan hasil akhir yang dapat disimpulkan. Sedangkan deskriptif maksudnya adalah dengan memaparkan masalah-masalah yang sudah ada atau tampak serta kesimpulan dari hasil analisis.

Data yang digunakan dalam penelitian ini adalah data mengenai kegiatan proyek dan hubungan ketergantungan antar kegiatan yang diperoleh secaara langsung maupun wawancara dan survei awal dengan pihak-pihak yang terkait pada bagian NPD di PT. XYZ. Gambar 1 merupakan langkah-langkah yang dilakukan dalam penelitian ini.

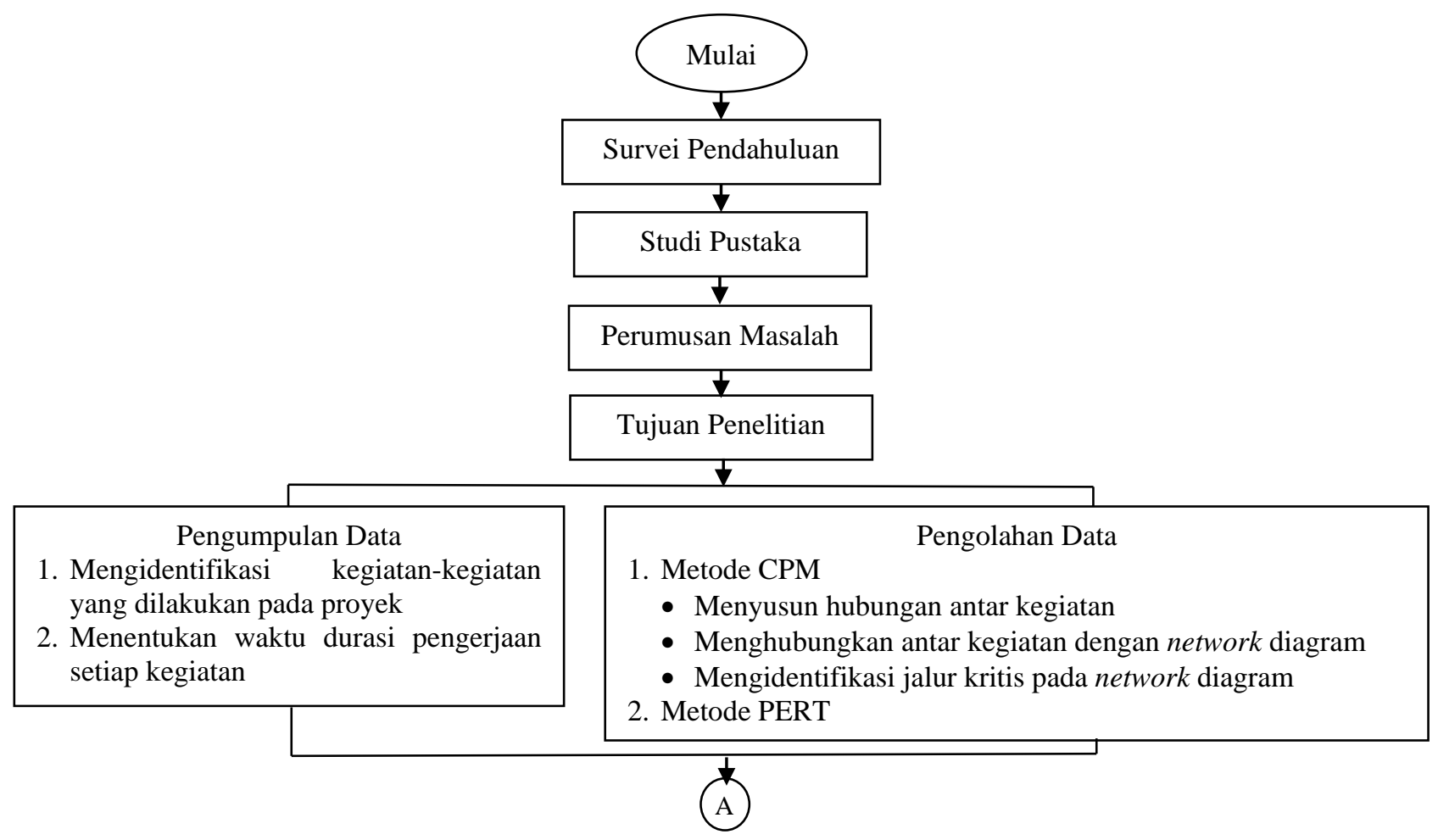

Gambar 1. Metode Penelitian 


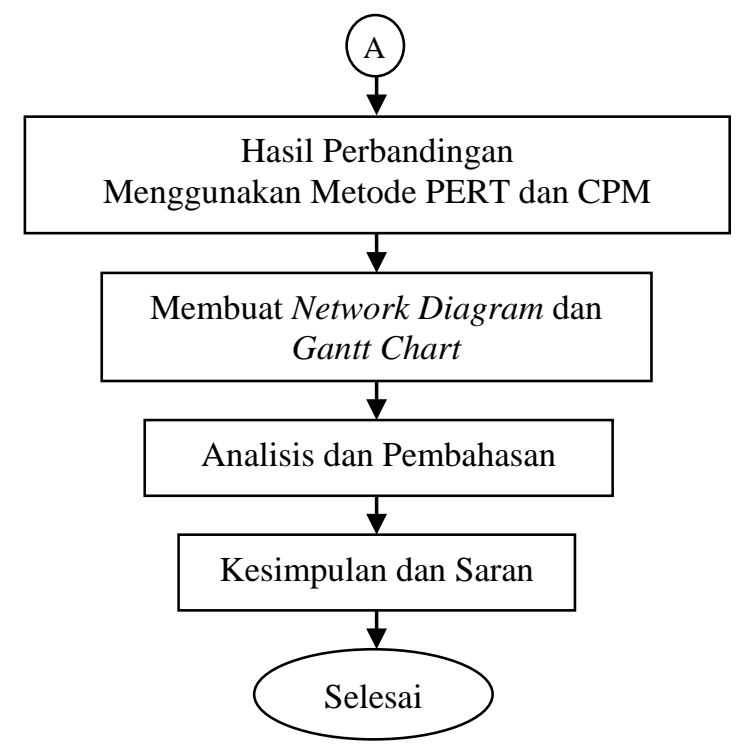

Lanjutan Gambar 1. Metode Penelitian

\section{HASIL DAN PEMBAHASAN}

Dalam penelitian ini pada awalnya mendeskripsikan kegiatan yaitu pengkajian dan pengidentifikasian lingkup proyek dengan menguraikan dan memecahkannya menjadi kegiatan-kegiatan atau kelompok kegiatan yang merupakan komponen proyek. Penyusunan ini dilakukan berdasarkan pengalaman dan atau data dalam proyek di masa lalu. Setiap kegiatan memiliki perkiraan waktu dalam proses pengerjaannya atau durasi yang disusun dalam master schedule. Selanjutnya menentukan hubungan antar kegiatan, yaitu kegiatan disusun kembali menjadi sebuah mata rantai, dimana urutan kegiatan sesuai dengan logika ketergantungan dalam network planning, sehingga diketahui urutan kegiatan dari awal dimulainya proyek sampai dengan selesainya proyek secara keseluruhan.

Tabel 1. Deskripsi Kegiatan dan Durasi Pengerjaan Kegiatan

\begin{tabular}{clcc}
\hline No & \multicolumn{1}{c}{ Jenis Pekerjaan } & $\begin{array}{c}\text { Kode } \\
\text { Kegiatan }\end{array}$ & $\begin{array}{c}\text { Durasi } \\
\text { (Hari) }\end{array}$ \\
\hline 1 & $\begin{array}{l}\text { Finalisasi Ide dan } \\
\text { Konsep }\end{array}$ & $\mathrm{A}$ & 14 \\
2 & $\begin{array}{l}\text { Sizing dan penentuan } \\
\text { Spesifikasi Kemasan }\end{array}$ & $\mathrm{B}$ & 2 \\
3 & $\begin{array}{l}\text { Pembuatan Tentative } \\
\text { Technical Drawing }\end{array}$ & $\mathrm{C}$ & 1 \\
4 & Pencarian Supplier & $\mathrm{D}$ & 3 \\
5 & Pembuatan sampel & $\mathrm{E}$ & 7 \\
6 & Trial lapangan & $\mathrm{F}$ & 7 \\
\hline
\end{tabular}

Lanjutan Tabel 1. Deskripsi Kegiatan dan Durasi Pengerjaan Kegiatan

\begin{tabular}{clcc}
\hline No & \multicolumn{1}{c}{ Jenis Pekerjaan } & $\begin{array}{c}\text { Kode } \\
\text { Kegiatan }\end{array}$ & $\begin{array}{c}\text { Durasi } \\
\text { (Hari) }\end{array}$ \\
\hline 7 & $\begin{array}{l}\text { Pembuatan Final } \\
\text { Technical Drawing }\end{array}$ & $\mathrm{G}$ & 1 \\
8 & Pembuatan Desain & $\mathrm{H}$ & 7 \\
9 & Design Approval & $\mathrm{I}$ & 7 \\
10 & Pembuatan Kontrak & $\mathrm{J}$ & 3 \\
& Supplier & & \\
11 & Proses Final Artwork & $\mathrm{K}$ & 7 \\
12 & Pengajuan Digital Proof & $\mathrm{L}$ & 7 \\
13 & Pembuatan Alat Cetak & $\mathrm{M}$ & 7 \\
14 & Pembuatan Color & $\mathrm{N}$ & 14 \\
& Range & & \\
15 & Proses Cetak & $\mathrm{O}$ & 10 \\
16 & Proses kirim & $\mathrm{P}$ & 7 \\
17 & First Production & $\mathrm{Q}$ & 7 \\
\hline
\end{tabular}

\section{Metode CPM}

Setelah mengetahui hubungan antar kegiatan dalam proyek selanjutnya menentukan jalur kritis. Jalur kritis pada proyek pengemasan kemasan adalah jalur yang terdiri dari rangkaian kegiatan yang apabila terjadi keterlambatan akan mengakibatkan keterlambatan secara keseluruhan. Pada langkah ini didahulukan dengan melakukan perhitungan maju dan perhitungan mundur. Perhitungan maju dilakukan untuk mengetahui Early Start (ES) dan Early Finish (EF) sedangkan perhitungan mundur untuk mengetahui Latest Start (LS) dan Latest Finish (LF). Dari kedua perhitungan tersebut dapat diidentifikasi jalur kritis yang 
dapat dihitung float/slack, yang merupakam kelonggaran waktu penyelesaian suatu kegiatan.

Tabel 2. Hubungan Antar Kegiatan

\begin{tabular}{clcc}
\hline $\begin{array}{c}\text { Kode } \\
\text { Kegiatan }\end{array}$ & \multicolumn{1}{c}{ Jenis Pekerjaan } & $\begin{array}{c}\text { Durasi } \\
\text { (hari) }\end{array}$ & $\begin{array}{c}\text { Kegiatan } \\
\text { Sebelumnya }\end{array}$ \\
\hline A & Finalisasi Ide dan Konsep & 14 & \\
B & Sizing dan Penentuan Spesifikasi Kemasan & 2 & A \\
C & Pembuatan Tentative Technical Drawing & 1 & B \\
D & Pencarian Supplier & 3 & C \\
E & Pembuatan Sampel & 7 & D \\
F & Trial Lapangan & 7 & E \\
G & Pembuatan Final Technical Drawing & 1 & F \\
H & Pembuatan Desain & 7 & C \\
I & Design Approval & 7 & G, H \\
J & Pembuatan Kontrak Supplier & 3 & I \\
K & Process \& Delivery & 7 & I \\
L & Pengajuan Digital Proof & 7 & K \\
M & Pembuatan Alat Cetak & 7 & J, L \\
N & Pembuatan Color Range & 14 & M \\
O & Proses Cetak & 10 & N \\
P & Proses Kirim & 7 & O \\
Q & First Production & 7 & P \\
\hline
\end{tabular}

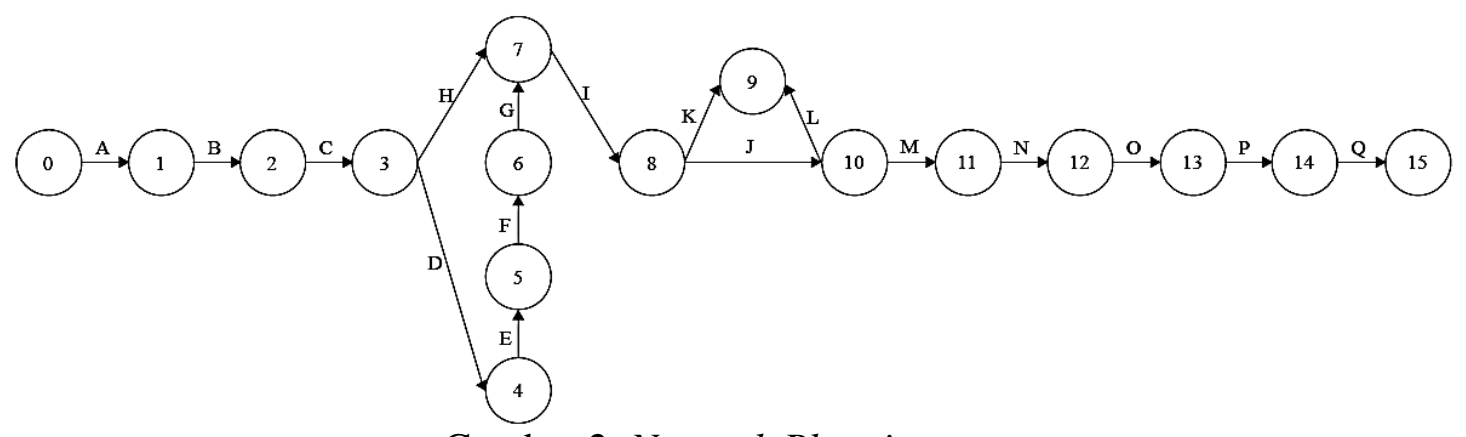

Gambar 2. Network Planning

Tabel 3. Perhitungan CPM

\begin{tabular}{|c|c|c|c|c|c|c|c|c|}
\hline \multirow[t]{2}{*}{ Kegiatan } & \multirow{2}{*}{$\begin{array}{c}\text { Durasi } \\
\text { (hari) }\end{array}$} & \multirow{2}{*}{$\begin{array}{c}\text { Kegiatan } \\
\text { Sebelumnya }\end{array}$} & \multicolumn{2}{|c|}{$\begin{array}{c}\text { Perhitungan } \\
\text { Maju }\end{array}$} & \multicolumn{2}{|c|}{$\begin{array}{l}\text { Perhitungan } \\
\text { Mundur }\end{array}$} & \multirow[t]{2}{*}{ FF } & \multirow[t]{2}{*}{$\mathrm{TF}$} \\
\hline & & & ES & EF & LS & LF & & \\
\hline A & 14 & & 0 & 14 & 0 & 14 & 0 & 0 \\
\hline B & 2 & A & 14 & 16 & 14 & 16 & 0 & 0 \\
\hline $\mathrm{C}$ & 1 & B & 16 & 17 & 17 & 20 & 0 & 3 \\
\hline D & 3 & $\mathrm{C}$ & 17 & 20 & 17 & 20 & 0 & 0 \\
\hline $\mathrm{E}$ & 7 & $\mathrm{D}$ & 20 & 27 & 20 & 27 & 0 & 0 \\
\hline $\mathrm{F}$ & 7 & $\mathrm{E}$ & 27 & 34 & 27 & 34 & 0 & 0 \\
\hline G & 1 & $\mathrm{~F}$ & 34 & 35 & 34 & 35 & 0 & 0 \\
\hline $\mathrm{H}$ & 7 & $\mathrm{C}$ & 17 & 24 & 17 & 35 & 3 & 11 \\
\hline I & 7 & $\mathrm{G}, \mathrm{H}$ & 35 & 42 & 35 & 42 & 0 & 0 \\
\hline $\mathrm{J}$ & 3 & I & 42 & 45 & 42 & 56 & 0 & 11 \\
\hline K & 7 & I & 42 & 49 & 42 & 49 & 0 & 0 \\
\hline $\mathrm{L}$ & 7 & $\mathrm{~K}$ & 49 & 56 & 49 & 56 & 0 & 0 \\
\hline M & 7 & J, L & 56 & 63 & 56 & 63 & 0 & 0 \\
\hline $\mathrm{N}$ & 14 & M & 63 & 77 & 63 & 77 & 0 & 0 \\
\hline $\mathrm{O}$ & 10 & $\mathrm{~N}$ & 77 & 87 & 77 & 87 & 0 & 0 \\
\hline $\mathrm{P}$ & 7 & $\mathrm{O}$ & 87 & 94 & 87 & 94 & 0 & 0 \\
\hline $\mathrm{Q}$ & 7 & $\mathrm{P}$ & 94 & 101 & 94 & 101 & 0 & 0 \\
\hline
\end{tabular}




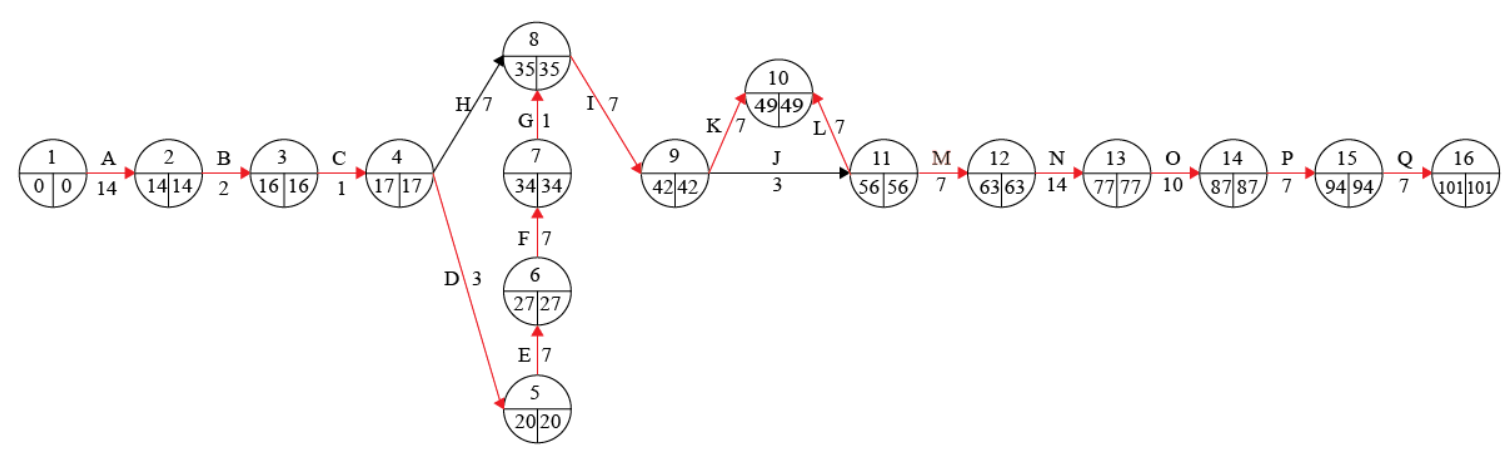

Gambar 3. Network Diagram Jalur Kritis CPM

Berdasarkan hasil perhitungan CPM, kemudian digambarkan dalam bentuk diagram network yang telah disesuaikan dengan hasil yang diperoleh. Berikut dapat dilihat pada Gambar 3 diagram network dengan menggunakan metode CPM.

Serangkaian aktivitas yang masuk ke dalam lintasan kritis dengan menggunakan metode CPM adalah jalur kritis yang berada pada lintasan A, B, C, D, E, F, G, I, K, L, M, N, $\mathrm{O}, \mathrm{P}$ dan $\mathrm{Q}$.

Berdasarkan pada Gambar 3 diperoleh waktu penyelesaian proyek dengan metode CPM dengan waktu 101 hari. Dengan analisis bahwa jalur A, B, C, D, E, F, G, I, K, L, M, N, $\mathrm{O}, \mathrm{P}$ dan $\mathrm{Q}$ merupakan jalur yang tidak memiliki tenggang waktu kerja antara selesainya satu tahap kegiatan dengan kegiatan lain dengan tahap mulainya kegiatan berikutnya.

\section{Metode PERT}

Jalur kritis network PERT diidentifikasi dengan perhitungan slack, yaitu aktivitas yang mempunyai nilai Free Slack (FS) dan Total Slack $(\mathrm{TS})=0$. Nilai Slack tersebut menunjukan jumlah waktu yang diperkenankkan suatu kegiatan boleh ditunda, tanpa mempengaruhi jumlah penyelesaian kegiatan secara keseluruhan, lalu dimasukan ke dalam diagram network setelah diketahui jalur kritisnya. Berikut merupakan hasil perhitungan jalur kritis menggunakan metode PERT ditunjukan pada Tabel 4.

Tabel 4. Perhitungan PERT

\begin{tabular}{|c|c|c|c|c|c|c|c|c|c|c|}
\hline \multirow[t]{2}{*}{ Kegiatan } & \multicolumn{3}{|c|}{ Durasi } & $\mathrm{Te}$ & \multicolumn{2}{|c|}{$\begin{array}{c}\text { Perhitungan } \\
\text { Maju }\end{array}$} & \multicolumn{2}{|c|}{$\begin{array}{c}\text { Perhitungan } \\
\text { Mundur }\end{array}$} & \multirow[t]{2}{*}{ FS } & \multirow[t]{2}{*}{ TS } \\
\hline & $\mathrm{T}_{0}$ & $\mathrm{~T}_{\mathrm{m}}$ & $\mathrm{T}_{\mathrm{p}}$ & & TEi & TEj & TLi & TLj & & \\
\hline A & 12 & 14 & 16 & 14 & 0 & 14 & 0 & 14 & 0 & 0 \\
\hline B & 1 & 2 & 3 & 2 & 14 & 16 & 14 & 16 & 0 & 0 \\
\hline $\mathrm{C}$ & 1 & 1 & 2 & 1 & 16 & 17 & 16 & 17 & 0 & 0 \\
\hline $\mathrm{D}$ & 2 & 3 & 5 & 3 & 17 & 20 & 17 & 20 & 0 & 0 \\
\hline $\mathrm{E}$ & 5 & 7 & 8 & 7 & 20 & 27 & 20 & 27 & 0 & 0 \\
\hline $\mathrm{F}$ & 5 & 7 & 10 & 7 & 27 & 34 & 27 & 34 & 0 & 0 \\
\hline G & 1 & 1 & 2 & 1 & 34 & 35 & 34 & 35 & 0 & 0 \\
\hline $\mathrm{H}$ & 6 & 7 & 9 & 7 & 17 & 35 & 17 & 35 & 0 & 0 \\
\hline I & 3 & 7 & 8 & 7 & 35 & 42 & 35 & 42 & 0 & 0 \\
\hline $\mathrm{J}$ & 1 & 3 & 4 & 3 & 42 & 45 & 42 & 56 & 0 & 11 \\
\hline $\mathrm{K}$ & 5 & 7 & 10 & 7 & 42 & 49 & 42 & 49 & 0 & 0 \\
\hline $\mathrm{L}$ & 4 & 7 & 7 & 7 & 49 & 56 & 49 & 56 & 0 & 0 \\
\hline M & 6 & 7 & 12 & 8 & 56 & 64 & 56 & 64 & 0 & 0 \\
\hline $\mathrm{N}$ & 10 & 14 & 19 & 14 & 64 & 78 & 64 & 78 & 0 & 0 \\
\hline $\mathrm{O}$ & 8 & 10 & 14 & 10 & 78 & 88 & 78 & 88 & 0 & 0 \\
\hline $\mathrm{P}$ & 5 & 7 & 10 & 7 & 88 & 95 & 88 & 95 & 0 & 0 \\
\hline $\mathrm{Q}$ & 3 & 7 & 8 & 7 & 95 & 102 & 95 & 102 & 0 & 0 \\
\hline
\end{tabular}

Ket: = Aktivitas/kegiatan kritis 


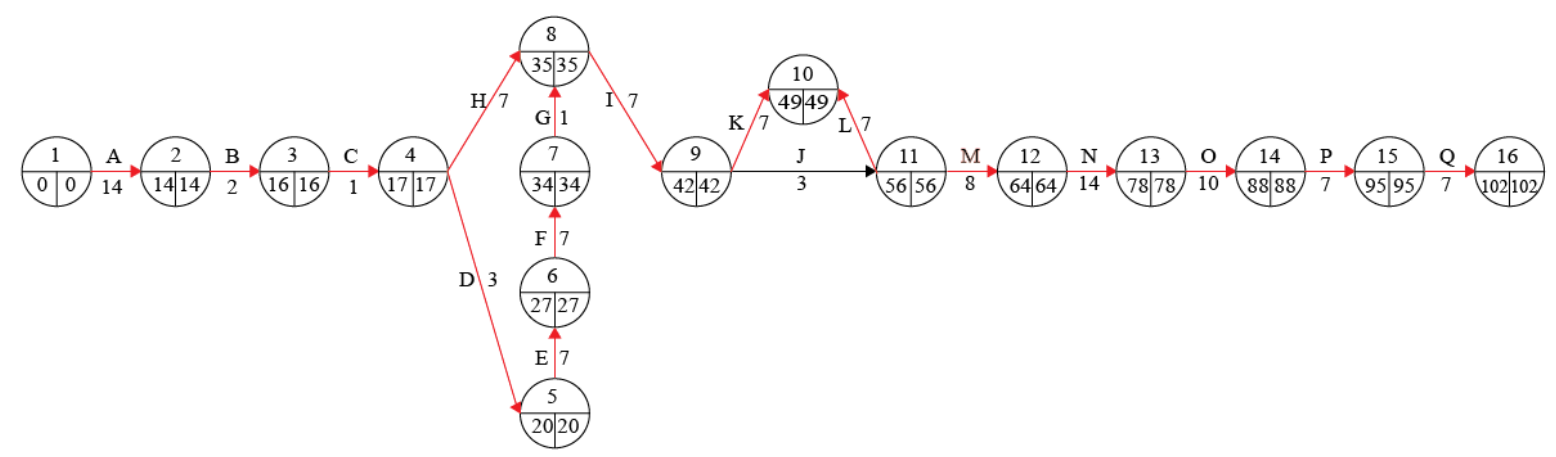

Gambar 4. Network Diagram Hasil Perhitungan PERT

Dari Tabel 4 di atas kemudian digambarkan dalam bentuk diagram network yang telah disesuaikan dengan hasil yang diperoleh. Berikut dapat kita lihat diagram network dengan menggunakan metode PERT yang ditunjukkan pada Gambar 4.

Setelah jalur kritis diketahui maka berikutnya adalah menghitung variansi (V) dan Deviasi Standard (S) untuk setiap kegiatan dengan rumus :

$\mathrm{S}=\left(\frac{T p-T o}{6}\right)^{2}$

$\mathrm{V}=\mathrm{S}^{2}$

Dengan menggunakan rumus di atas, maka diperoleh hasil perhitungan seperti terlihat pada Tabel 5 di bawah ini:

Tabel 5. Hasil Variansi (V) dan Deviasi Standart (S)

\begin{tabular}{|c|c|c|c|c|c|}
\hline \multirow{2}{*}{ Kegiatan } & \multicolumn{3}{|c|}{ Durasi } & \multirow{2}{*}{ S } & \multirow{2}{*}{ V } \\
\hline & $\mathrm{T}_{\mathrm{o}}$ & $\mathrm{T}_{\mathrm{m}}$ & $\mathrm{T}_{\mathrm{p}}$ & & \\
\hline A & 12 & 14 & 16 & 0,44 & 0,19 \\
\hline B & 1 & 2 & 3 & 0,11 & 0,01 \\
\hline $\mathrm{C}$ & 1 & 1 & 2 & 0,00 & 0,00 \\
\hline $\mathrm{D}$ & 2 & 3 & 5 & 0,25 & 0,06 \\
\hline $\mathrm{E}$ & 5 & 7 & 8 & 0,25 & 0,06 \\
\hline F & 5 & 7 & 10 & 0,69 & 0,48 \\
\hline G & 1 & 1 & 2 & 0,02 & 0,00 \\
\hline $\mathrm{H}$ & 6 & 7 & 9 & 0,25 & 0,06 \\
\hline I & 3 & 7 & 8 & 0,69 & 0,48 \\
\hline $\mathrm{J}$ & 1 & 3 & 4 & 0,25 & 0,06 \\
\hline $\mathrm{K}$ & 5 & 7 & 10 & 0,69 & 0,48 \\
\hline $\mathrm{L}$ & 4 & 7 & 7 & 0,25 & 0,06 \\
\hline M & 6 & 7 & 12 & 1,00 & 1,00 \\
\hline $\mathrm{N}$ & 10 & 14 & 19 & 2,25 & 5,06 \\
\hline $\mathrm{O}$ & 8 & 10 & 14 & 1,00 & 1,00 \\
\hline $\mathrm{P}$ & 5 & 7 & 10 & 0,69 & 0,48 \\
\hline $\mathrm{Q}$ & 3 & 7 & 8 & 0,69 & 0,48 \\
\hline
\end{tabular}

Dalam perhitungan waktu penyelesaian menggunakan metode PERT dapat diketahui kemungkinan atau probabilitas waktu penyelesaian kegiatan proyek yaitu dengan cara menggunakan aktivitas kritis yaitu $\mathrm{A}, \mathrm{B}, \mathrm{C}, \mathrm{D}$, E, F, G, H, I, K, L, M, N, O, Q. Adapun perhitungannya adalah sebagai berikut:

Te kritis $=102$ hari,

TD = 101 hari (asumsi penyelesaian CPM)

$$
\begin{aligned}
\sum \mathrm{v} \text { kritis }= & \mathrm{v}(\mathrm{A})+\mathrm{v}(\mathrm{B})+\mathrm{v}(\mathrm{C})+\mathrm{v}(\mathrm{D})+\mathrm{v}(\mathrm{E}) \\
& +\mathrm{v}(\mathrm{F})+\mathrm{v}(\mathrm{G})+\mathrm{v}(\mathrm{H})+\mathrm{v}(\mathrm{I})+\mathrm{v}(\mathrm{K}) \\
& +\mathrm{v}(\mathrm{L})+\mathrm{v}(\mathrm{M})+\mathrm{v}(\mathrm{N})+\mathrm{v}(\mathrm{O})+ \\
& \mathrm{v}(\mathrm{Q}) \\
= & 0,19+0,01+0+0,06+0,06+ \\
& 0,48+0+0,06+0,48+0,48+ \\
& 0,06+1+5,06+1+0,48+0,48 \\
= & 9,9
\end{aligned}
$$

$\mathrm{Z}=\frac{\mathrm{TD}-\sum \text { Te kritis }}{\sqrt{\sum \mathrm{V} \text { kritis }}}=\frac{101-102}{\sqrt{9,9}}$

$Z=-0,32$

$\mathrm{Z}=0,6255$ (dari tabel $\mathrm{Z}$ distribusi normal)

Probabilitas $=1-0,6255=0,3745$

Berdasarkan perhitungan di atas didapat $\mathrm{Z}=-0,32$ dan didapatkan 0,6255 (dari tabel distribusi normal), serta didapatkan juga nilai kemungkinan atau probabilitas menyelesaikan proyek adalah 37\%. Hal ini berarti bahwa kemungkinan kegiatan proyek development packaging dapat selesai tepat waktu cukup rendah. 
Perbandingan waktu pengerjaan proyek development packaging dengan kedua metode ini dapat dilihat pada Tabel 6 dan Gambar 5.

Tabel 6. Perbandingan Waktu Menggunakan Metode CPM dan PERT

\begin{tabular}{cccc}
\hline Uraian & CPM & PERT & Selisih \\
\hline Waktu (hari) & 101 & 102 & 1 \\
\hline
\end{tabular}

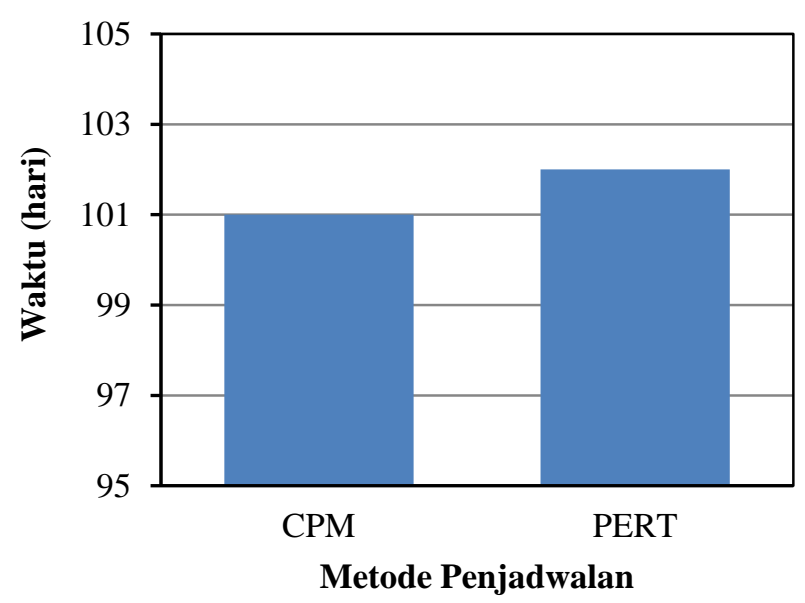

Gambar 5. Grafik Perbandingan Metode Terhadap Waktu Penyelesaian Proyek

\section{KESIMPULAN}

Berdasarkan analisis data dan pembahasan yang telah dilakukan sebelumnya maka kesimpulan yang dapat diambil dalam penelitian ini adalah bahwa penyelesaian proyek dengan menggunakan metode penjadwalan CPM adalah sebesar 101 hari sedangkan dengan menggunakan metode PERT waktu penyelesaian proyek sebesar 102 hari. Namun apabila tanpa menggunakan kedua metode tersebut waktu penyelesaian proyek memakan waktu 154 hari. Dari kedua metode CPM dan PERT dengan mempertimbangkan kondisi aktual yang ideal maka metode CPM menghasilkan durasi penyelesaian keseluruhan proyek lebih singkat dibandingkan dengan metode PERT. Jadi dengan menggunakan metode CPM, perusahaan dapat menghemat waktu sebanyak 53 hari dan dapat terjadi efisiensi waktu dengan menggunakan network planning. Dengan menggunakan Network Planning menggunakan metode CPM (Critical Path Method) sebagai alat bantu, perusahaan dapat mengetahui kegiatan mana saja yang perlu diprioritaskan pengerjaannya sehngga tidak mengalami keterlambatan dalam penyelesaian proyek. Perencanaan awal dalam teknik penentuan jadwal harus lebih matang agar mempermudah pada saat implementasi jadwal proyek.

\section{DAFTAR PUSTAKA}

[1] Agyei, Wallace. 2015. Project Planning And Scheduling Using PERT And CPM Techniques With Linear Programming: Case Study. International Journal of Scientific \& Technology Research. 4(8). 222-227.

[2] Chatwal. 2014. Aplication of Project Scheduling in a Bottling Unit Startup Using PERT and CPM Techniques. International Journal of Advanced Research in Engineering and Applied Science. Vol 3,No.6.

[3] Soeharto, Imam. 2001. Manajemen Proyek Dari Konseptual Sampai Operasional. Jakarta: Erlangga.

[4] Ervianto, Wulfram., 2002. Manajemen Proyek Konstruksi. Yogyakarta: Andi

[5] Manahan,T. 2004. Manajemen Operasi, Ghalia Indonesia

[6] Dimyanti, Hamdan,H.A., \& Nurjaman, K., 2014. Manajemen Proyek. Bandung : Pustaka Setia

[7] Nurhayati. 2010. Manajemen Proyek. Yogyakarta : Graha Ilmu 